\title{
Lack of Natural Scientific Ability
}

Back in March President Trump suggested he would have thrived in another profession, medical expert (1). Despite no training or experience, Trump boasted "I like this stuff. I really get it". Citing a "great, super-genius uncle" who taught at MIT, Trump professed that it must run in the family genes. Trump went on to say "People are really surprised I understand this stuff ... Maybe I have a natural ability."

This was followed by a series of White House briefings where Trump and members of his White House Coronavirus Task Force spoke on the COVID-19 pandemic. Trump tried to dominate these conferences and repeatedly lied about the coronavirus pandemic and the country's preparation for this once-in-a-generation crisis. Below is a partial list of 35 of the biggest lies about the COVID-19 pandemic he's told as the nation endures a public-health and economic calamity are in Table 1 (2).

Table 1. Partial list of Trump lies regarding the COVID-19 pandemic (2).

\begin{tabular}{|l|l|l|}
\hline Date & Trump claim & Truth \\
\hline $2 / 7 / 20$ & $\begin{array}{l}\text { The coronavirus would weaken } \\
\text { "when we get into April, in the } \\
\text { warmer weather-that has a very } \\
\text { negative effect on that, and that } \\
\text { type of a virus." }\end{array}$ & $\begin{array}{l}\text { Respiratory viruses can be seasonal, } \\
\text { but the COVID-19 can be transmitted } \\
\text { in ALL AREAS, including areas with } \\
\text { hot and humid weather and is clearly } \\
\text { not diminishing. }\end{array}$ \\
\hline $2 / 27 / 20$ & $\begin{array}{l}\text { The outbreak would be temporary: } \\
\text { "It's going to disappear. One day } \\
\text { it's like a miracle-it will } \\
\text { disappear." }\end{array}$ & $\begin{array}{l}\text { Anthony Fauci, the director of the } \\
\text { National Institute of Allergy and } \\
\text { Infectious Diseases, warned days later } \\
\text { that he was concerned that "as the } \\
\text { next week or two or three go by, we're } \\
\text { going to see a lot more community- } \\
\text { related cases." }\end{array}$ \\
\hline $\begin{array}{l}\text { Multiple } \\
\text { times }\end{array}$ & $\begin{array}{l}\text { The claim: If the economic } \\
\text { shutdown continues, deaths by } \\
\text { suicide "definitely would be in far } \\
\text { greater numbers than the numbers } \\
\text { that we're talking about" for } \\
\text { cOVID-19 deaths. }\end{array}$ & $\begin{array}{l}\text { suicide in the US in 2017 was roughly nowhere near the COVID-19 } \\
\text { deaths now at about 147,000 (3). }\end{array}$ \\
\hline $\begin{array}{l}\text { Multiple } \\
\text { times }\end{array}$ & $\begin{array}{l}\text { "Coronavirus numbers are looking } \\
\text { MUCH better, going down almost } \\
\text { everywhere," and cases are } \\
\text { "coming way down." }\end{array}$ & $\begin{array}{l}\text { Most states now have rising COVID-19 } \\
\text { cases, hospitalizations and deaths (3). }\end{array}$ \\
\hline $7 / 2 / 20$ & $\begin{array}{l}\text { The pandemic is "getting under } \\
\text { control." }\end{array}$ & $\begin{array}{l}\text { Most states now have rising COVID-19 } \\
\text { cases, hospitalizations and deaths (3). } \\
\text { It is not under control. }\end{array}$ \\
\hline $7 / 4 / 20$ & $\begin{array}{l}\text { "99\%" ovidence shows that the virus } \\
\text { "can make you seriously ill" even if it } \\
\text { "totally harmless." }\end{array}$ \\
\hline
\end{tabular}




\begin{tabular}{|c|c|c|}
\hline $7 / 6 / 20$ & $\begin{array}{l}\text { "We now have the lowest Fatality } \\
\text { (Mortality) Rate in the World." }\end{array}$ & $\begin{array}{l}\text { The U.S. has neither the lowest } \\
\text { mortality rate nor the lowest case- } \\
\text { fatality rate (3). }\end{array}$ \\
\hline $3 / 4 / 20$ & $\begin{array}{l}\text { "The Obama administration made } \\
\text { a decision on [laboratory] testing } \\
\text { that turned out to be very } \\
\text { detrimental to what we're doing." }\end{array}$ & $\begin{array}{l}\text { The Trump White House rolled back } \\
\text { Food and Drug Administration } \\
\text { regulations that limited the kind of } \\
\text { laboratory tests states could run and } \\
\text { how they could conduct them. }\end{array}$ \\
\hline $3 / 13 / 20$ & $\begin{array}{l}\text { The Obama White House's } \\
\text { response to the H1N1 pandemic } \\
\text { was "a full scale disaster, with } \\
\text { thousands dying, and nothing } \\
\text { meaningful done to fix the testing } \\
\text { problem, until now." }\end{array}$ & $\begin{array}{l}\text { Barack Obama declared a public- } \\
\text { health emergency two weeks after the } \\
\text { first U.S. cases of H1N1 were } \\
\text { reported, in California. Trump declared } \\
\text { a national emergency more than sever } \\
\text { weeks after the first domestic COVID- } \\
19 \text { case was reported, in Washington } \\
\text { State. While testing is a problem now, } \\
\text { it wasn't back in } 2009 \text {. The challenge } \\
\text { then was vaccine development: } \\
\text { Production was delayed and the } \\
\text { vaccine wasn't distributed until the } \\
\text { outbreak was already waning. }\end{array}$ \\
\hline $\begin{array}{l}\text { Multiple } \\
\text { times }\end{array}$ & $\begin{array}{l}\text { The Trump White House } \\
\text { "inherited" a "broken," "bad," and } \\
\text { "obsolete" test for the coronavirus. }\end{array}$ & $\begin{array}{l}\text { The novel coronavirus did not exist in } \\
\text { humans during the Obama } \\
\text { administration. }\end{array}$ \\
\hline $\begin{array}{l}\text { Multiple } \\
\text { times }\end{array}$ & $\begin{array}{l}\text { The Obama administration left } \\
\text { Trump "bare" and "empty" shelves } \\
\text { of medical supplies in the national } \\
\text { strategic stockpile. }\end{array}$ & $\begin{array}{l}\text { The stockpile's former director said in } \\
2019 \text {, before the coronavirus } \\
\text { pandemic, that it was well-equipped. } \\
\text { The outbreak has since eaten away at } \\
\text { its reserves. }\end{array}$ \\
\hline $5 / 10 / 20$ & $\begin{array}{l}\text { Trump attacked "Joe Biden's } \\
\text { handling of the H1N1 Swine Flu." }\end{array}$ & $\begin{array}{l}\text { Biden was not responsible for the } \\
\text { federal government's response to the } \\
\text { H1N1 outbreak. }\end{array}$ \\
\hline $\begin{array}{l}3 / 6 / 20 \\
\& \\
5 / 11 / 20\end{array}$ & $\begin{array}{l}\text { "Anybody that needs a test, gets a } \\
\text { test. We-they're there. They have } \\
\text { the tests. And the tests are } \\
\text { beautiful" and "If somebody wants } \\
\text { to be tested right now, they'll be } \\
\text { able to be tested." }\end{array}$ & $\begin{array}{l}\text { Trump made these two claims two } \\
\text { months apart, but the truth is still the } \\
\text { same: The U.S. does not have enough } \\
\text { testing. }\end{array}$ \\
\hline $\begin{array}{l}3 / 24 \& \\
3 / 25 / 20\end{array}$ & $\begin{array}{l}\text { The United States has outpaced } \\
\text { South Korea's COVID-19 testing: } \\
\text { "We're going up proportionally } \\
\text { very rapidly," Trump said during a } \\
\text { Fox News town hall. }\end{array}$ & $\begin{array}{l}\text { When the president made this claim, } \\
\text { testing in the U.S. was severely } \\
\text { lagging behind that in South Korea. As } \\
\text { of March } 25 \text {, South Korea had } \\
\text { conducted about five times as many } \\
\text { tests as a proportion of its population } \\
\text { relative to the United States. }\end{array}$ \\
\hline
\end{tabular}




\begin{tabular}{|c|c|c|}
\hline $5 / 11 / 20$ & $\begin{array}{l}\text { America has "developed a testing } \\
\text { capacity unmatched and unrivaled } \\
\text { anywhere in the world, and it's not } \\
\text { even close." }\end{array}$ & $\begin{array}{l}\text { The United States is still not testing } \\
\text { enough people and is lagging behind } \\
\text { the testing and tracing capabilities that } \\
\text { other countries have developed. }\end{array}$ \\
\hline $\begin{array}{l}\text { Multiple } \\
\text { times }\end{array}$ & $\begin{array}{l}\text { "Cases are going up in the U.S. } \\
\text { because we are testing far more } \\
\text { than any other country." }\end{array}$ & $\begin{array}{l}\text { COVID-19 cases are not rising } \\
\text { because of "our big-number testing." } \\
\text { Outside the Northeast, the share of } \\
\text { tests conducted that come back } \\
\text { positive is increasing, with the } \\
\text { sharpest spike happening in southern } \\
\text { states. In some states, such as } \\
\text { Arizona and Florida, the number of } \\
\text { new cases being reported is outpacing } \\
\text { any increase in the states' testing } \\
\text { ability. And as states set new daily } \\
\text { case records and report increasing } \\
\text { hospitalizations, all signs point to a } \\
\text { worsening crisis. }\end{array}$ \\
\hline $3 / 11 / 20$ & $\begin{array}{l}\text { The United States would suspend } \\
\text { "all travel from Europe, except the } \\
\text { United Kingdom, for the next } 30 \\
\text { days." }\end{array}$ & $\begin{array}{l}\text { The travel restriction would not apply } \\
\text { to U.S. citizens, legal permanent } \\
\text { residents, or their families returning } \\
\text { from Europe. }\end{array}$ \\
\hline $3 / 12 / 20$ & $\begin{array}{l}\text { All U.S. citizens arriving from } \\
\text { Europe would be subject to } \\
\text { medical screening, COVID-19 } \\
\text { testing, and quarantine if } \\
\text { necessary. "If an American is } \\
\text { coming back or anybody is coming } \\
\text { back, we're testing," Trump said. } \\
\text { "We have a tremendous testing } \\
\text { setup where people coming in } \\
\text { have to be tested ... We're not } \\
\text { putting them on planes if it shows } \\
\text { positive, but if they do come here, } \\
\text { we're quarantining." }\end{array}$ & $\begin{array}{l}\text { Testing was already severely limited in } \\
\text { the United States at the time Trump } \\
\text { made this claim. It was not true that all } \\
\text { Americans returning to the country are } \\
\text { being tested, nor that anyone is being } \\
\text { forced to quarantine. }\end{array}$ \\
\hline $3 / 31 / 20$ & $\begin{array}{l}\text { "We stopped all of Europe" with a } \\
\text { travel ban. "We started with certain } \\
\text { parts of Italy, and then all of Italy. } \\
\text { Then we saw Spain. Then I said, } \\
\text { 'Stop Europe; let's stop Europe. } \\
\text { We have to stop them from } \\
\text { coming here."” }\end{array}$ & $\begin{array}{l}\text { The travel ban applied to the } \\
\text { Schengen Area, as well as the United } \\
\text { Kingdom and Ireland, and not all of } \\
\text { Europe as he claimed. }\end{array}$ \\
\hline $\begin{array}{l}\text { Multiple } \\
\text { times }\end{array}$ & $\begin{array}{l}\text { "Everybody thought I was wrong" } \\
\text { about implementing restrictions on } \\
\text { travelers from China, and "most } \\
\text { people felt they should not close it }\end{array}$ & $\begin{array}{l}\text { The travel ban was the "uniform" } \\
\text { recommendation of the Department of } \\
\text { Health and Human Services. }\end{array}$ \\
\hline
\end{tabular}




\begin{tabular}{|c|c|c|}
\hline & $\begin{array}{l}\text { down-that we shouldn't close } \\
\text { down to China." }\end{array}$ & \\
\hline $\begin{array}{l}\text { Multiple } \\
\text { times }\end{array}$ & $\begin{array}{l}\text { travel restrictions on China were a } \\
\text { "ban" that closed up the "entire" } \\
\text { United States and "kept China } \\
\text { out." }\end{array}$ & $\begin{array}{l}\text { Nearly } 40,000 \text { people traveled from } \\
\text { China to the United States from } \\
\text { February 2, when Trump's travel } \\
\text { restrictions went into effect, to April } 4 .\end{array}$ \\
\hline $3 / 17 / 20$ & $\begin{array}{l}\text { I've always known this is a real-- } \\
\text { this is a pandemic. I felt it was a } \\
\text { pandemic long before it was called } \\
\text { a pandemic ... l've always viewed } \\
\text { it as very serious." }\end{array}$ & $\begin{array}{l}\text { Trump has repeatedly downplayed the } \\
\text { significance of COVID-19 as outbreaks } \\
\text { began stateside. From calling criticism } \\
\text { of his handling of the virus a "hoax," to } \\
\text { comparing the coronavirus to a } \\
\text { common flu, to worrying about letting } \\
\text { sick Americans off cruise ships } \\
\text { because they would increase the } \\
\text { number of confirmed cases, Trump } \\
\text { has used his public statements to send } \\
\text { mixed messages and sow doubt about } \\
\text { the outbreak's seriousness. }\end{array}$ \\
\hline $3 / 26 / 20$ & $\begin{array}{l}\text { This kind of pandemic "was } \\
\text { something nobody thought could } \\
\text { happen ... Nobody would have } \\
\text { ever thought a thing like this could } \\
\text { have happened." }\end{array}$ & $\begin{array}{l}\text { Experts both inside and outside the } \\
\text { federal government sounded the alarm } \\
\text { many times in the past decade about } \\
\text { the potential for a devastating global } \\
\text { pandemic. }\end{array}$ \\
\hline $3 / 2 / 20$ & $\begin{array}{l}\text { Pharmaceutical companies are } \\
\text { going "to have vaccines, I think, } \\
\text { relatively soon." }\end{array}$ & $\begin{array}{l}\text { The president's own experts told him } \\
\text { during a White House meeting with } \\
\text { pharmaceutical leaders earlier that } \\
\text { same day that a vaccine could take a } \\
\text { year to } 18 \text { months to develop. }\end{array}$ \\
\hline $3 / 19 / 20$ & $\begin{array}{l}\text { Trump said the FDA had approved } \\
\text { the antimalarial drug chloroquine } \\
\text { to treat COVID-19. "Normally the } \\
\text { FDA would take a long time to } \\
\text { approve something like that, and } \\
\text { it's-it was approved very, very } \\
\text { quickly and it's now approved by } \\
\text { prescription," he said. }\end{array}$ & $\begin{array}{l}\text { FDA Commissioner Stephen Hahn } \\
\text { quickly clarified that the drug still had } \\
\text { to be tested in a clinical setting. }\end{array}$ \\
\hline $3 / 23 / 20$ & $\begin{array}{l}\text { Trump suggested in a briefing on } \\
\text { April } 23 \text { that his medical experts } \\
\text { should research the use of } \\
\text { powerful light and injected } \\
\text { disinfectants to treat COVID-19. }\end{array}$ & $\begin{array}{l}\text { Trump walked this statement back the } \\
\text { next day, saying he was being } \\
\text { "sarcastic". }\end{array}$ \\
\hline $5 / 8 / 20$ & $\begin{array}{l}\text { The coronavirus is "going to go } \\
\text { away without a vaccine ... and } \\
\text { we're not going to see it again, } \\
\text { hopefully, after a period of time." }\end{array}$ & $\begin{array}{l}\text { Tony Fauci has said that until there is } \\
\text { "a scientifically sound, safe, and } \\
\text { effective vaccine" the pandemic will } \\
\text { not be over. }\end{array}$ \\
\hline
\end{tabular}




\begin{tabular}{|c|c|c|}
\hline $\begin{array}{l}\text { Multiple } \\
\text { times }\end{array}$ & $\begin{array}{l}\text { Taking hydroxychloroquine to treat } \\
\text { COVID-19 is safe. "You're not } \\
\text { going to get sick or die," Trump } \\
\text { said on one occasion. "It doesn't } \\
\text { hurt people," he commented on } \\
\text { another. }\end{array}$ & $\begin{array}{l}\text { Trump's own FDA has warned against } \\
\text { taking the antimalarial drug with or } \\
\text { without the antibiotic azithromycin, } \\
\text { which Trump has also promoted. }\end{array}$ \\
\hline $5 / 9 / 20$ & $\begin{array}{l}\text { "One bad" study from the } \\
\text { Department of Veterans Affairs } \\
\text { that found no benefit among } \\
\text { veterans who took } \\
\text { hydroxychloroquine to treat } \\
\text { COVID-19 was run by "people that } \\
\text { aren't big Trump fans." The study } \\
\text { "was a Trump-enemy statement." }\end{array}$ & $\begin{array}{l}\text { There's no evidence that the study } \\
\text { was a political plot orchestrated by } \\
\text { Trump opponents, and it reached } \\
\text { similar conclusions as other } \\
\text { observational reports. The VA study } \\
\text { was led by independent researchers } \\
\text { from the University of Virginia and the } \\
\text { University of South Carolina with a } \\
\text { grant from the National Institutes of } \\
\text { Health. }\end{array}$ \\
\hline $3 / 20 / 20$ & $\begin{array}{l}\text { Trump twice said during a task- } \\
\text { force briefing that he had invoked } \\
\text { the Defense Production Act (DPA), } \\
\text { a Korean War-era law that } \\
\text { enables the federal government to } \\
\text { order private industry to produce } \\
\text { certain items and materials for } \\
\text { national use. He also said the } \\
\text { federal government was already } \\
\text { using its authority under the law: } \\
\text { "We have a lot of people working } \\
\text { very hard to do ventilators and } \\
\text { various other things." }\end{array}$ & $\begin{array}{l}\text { Federal Emergency Management } \\
\text { Agency Administrator Peter Gaynor } \\
\text { told CNN on March } 22 \text { that the } \\
\text { president has not actually used the } \\
\text { DPA to order private companies to } \\
\text { produce anything. Shortly after that, } \\
\text { Trump backtracked, saying that he had } \\
\text { not compelled private companies to } \\
\text { take action. Then, on March } 24 \text {, } \\
\text { Gaynor told CNN that FEMA plans to } \\
\text { use the DPA to allocate } 60,000 \text { test } \\
\text { kits. Trump tweeted afterward that the } \\
\text { DPA would not be used. }\end{array}$ \\
\hline $3 / 21 / 20$ & $\begin{array}{l}\text { Automobile companies that have } \\
\text { volunteered to manufacture } \\
\text { medical equipment, such as } \\
\text { ventilators, are "making them right } \\
\text { now." }\end{array}$ & $\begin{array}{l}\text { Ford and General Motors, which } \\
\text { Trump mentioned at a task-force } \\
\text { briefing the same day, announced } \\
\text { earlier in March that they had halted all } \\
\text { factory production in North America } \\
\text { and were likely months away from } \\
\text { beginning production of ventilators. }\end{array}$ \\
\hline $3 / 24 / 20$ & $\begin{array}{l}\text { Governor Andrew Cuomo of New } \\
\text { York passed on an opportunity to } \\
\text { purchase } 16,000 \text { ventilators at a } \\
\text { low cost in } 2015 \text {, Trump said } \\
\text { during the Fox News town hall. }\end{array}$ & $\begin{array}{l}\text { Trump seems to have gleaned this } \\
\text { claim from a Gateway Pundit article. } \\
\text { There is no evidence that Cuomo was } \\
\text { offered the ventilators or turned any } \\
\text { offer down. }\end{array}$ \\
\hline $3 / 29 / 20$ & $\begin{array}{l}\text { Trump "didn't say" that governors } \\
\text { do not need all the medical } \\
\text { equipment they are requesting } \\
\text { from the federal government. And } \\
\text { he "didn't say" that governors }\end{array}$ & $\begin{array}{l}\text { Trump told Fox News' Sean Hannity } \\
\text { on Thursday, March } 26 \text {, that "a lot of } \\
\text { equipment's being asked for that I } \\
\text { don't think they'll need," referring to } \\
\text { requests from the governors of }\end{array}$ \\
\hline
\end{tabular}




\begin{tabular}{|l|l|l|}
\hline & $\begin{array}{l}\text { should be more appreciative of the } \\
\text { help. }\end{array}$ & $\begin{array}{l}\text { Michigan, New York, and Washington. } \\
\text { He also said, during a Friday, March } \\
\text { 27, task-force briefing, that he wanted } \\
\text { state leaders "to be appreciative ... } \\
\text { We've done a great job." }\end{array}$ \\
\hline $\begin{array}{l}\text { W/29 } \\
\text { 3/30/20 }\end{array}$ & $\begin{array}{l}\text { Hospitals are reporting an } \\
\text { artificially inflated need for masks } \\
\text { and equipment, items that might } \\
\text { be "going out the back door," } \\
\text { Trump said on two separate days. } \\
\text { He also said he was not talking } \\
\text { about hoarding: "I think maybe it's } \\
\text { worse than hoarding." }\end{array}$ & $\begin{array}{l}\text { There is no evidence to show that } \\
\text { hospitals are maliciously hoarding or } \\
\text { inflating their need for masks and } \\
\text { personal protective equipment when } \\
\text { reporting shortages in supplies. }\end{array}$ \\
\hline $4 / 14 / 20$ & $\begin{array}{l}\text { Asked about his past praise of } \\
\text { China and its transparency, Trump } \\
\text { said that he hadn't "talk[ed] about } \\
\text { China's transparency." }\end{array}$ & $\begin{array}{l}\text { Trump lauded the country in tweets he } \\
\text { sent in late January and early } \\
\text { February. In one, he highlighted the } \\
\text { Chinese government's "transparency" } \\
\text { about the coronavirus outbreak. }\end{array}$ \\
\hline $3 / 29 / 20$ & $\begin{array}{l}\text { WHO ignored "credible reports" of } \\
\text { the coronavirus's spread in } \\
\text { Wuhan, the Chinese city that first } \\
\text { reported the new virus, including } \\
\text { those published in The Lancet } \\
\text { medical journal in December. }\end{array}$ & $\begin{array}{l}\text { reports in December. Its first reports } \\
\text { on the virus's spread in Wuhan were } \\
\text { published on January 24. }\end{array}$ \\
\hline
\end{tabular}

Trump eventually stopped the news briefings in face of their declining popularity and public trust and being outshone by Tony Fauci MD, director of National Institute of Allergy and Infectious Disease. Fauci is best known as an expert virologist for his handling of the Acquired Immunodeficiency Disease Syndrome (AIDS). He has faithfully served his patients, the American people, through six presidential administrations, providing sound, science-based guidance. However, he has been wrong. Two examples are not recommending masks early in the COVID-19 pandemic and stating that few COVID-19 patients were asymptomatic (4). However, both were based on the best available scientific evidence of the time which turned out to be wrong. In neither instance was Fauci's honesty questioned and, in both instances, Fauci self-corrected those errors.

The strained relationship between the White House and Fauci has been apparent for months. Trump was visibly annoyed when Fauci spoke at news briefings (5). In April Trump retweeted a call to fire Fauci during early criticism of Trump's mishandling of the COVID-19 pandemic (6). He has attempted to silence Fauci's inconvenient scientific voice from testifying before Congress and giving TV interviews (7). More recently, he has tried an old tactic of having aides and underlings attack opponents and then evaluating how it plays with the public. If it goes well Trump repeats it, but if it does not, he says the aide was acting on his own. The White House let their top economic advisor, Peter Navarro, attack Fauci in an USA Today op-ed (8). Last Sunday, White 
House scientific advisor Brett Girori MD tried to undermine Fauci last Sunday on Meet the Press saying Fauci only looks at the COVID-19 pandemic from "a very narrow public health point of view"; doesn't "have the whole national interest in mind'; and repeated the White House opposition to Fauci's call for states experiencing COVID-19 surges to pause their reopening processes (9).

The attacks against Fauci were apparently unsuccessful. Referring to the White House attacks, Fauci remained calm saying, "I cannot figure out in my wildest dreams why they would want to do that" (10). New polling from Quinnipiac University found that $65 \%$ of voters trust the information Fauci is providing about the coronavirus while only $30 \%$ trust the information provided by Trump (11). In the face of the polls favorable to Fauci, the White House is now distancing itself from Navarro saying he went rogue failing to obtain proper clearance for his op-ed (12).

In a closely related event, the Trump Administration has mandated that hospitals sidestep the Centers for Disease Control and Prevention and send critical information about COVID-19 hospitalizations and equipment to a different federal database (13). From the start of the pandemic, the CDC has collected data on COVID-19 hospitalizations, availability of intensive care beds and personal protective equipment. The change sparked concerns that the administration was hobbling the ability of the nation's public health agency to gather and analyze crucial data in the midst of a pandemic. It further allows data to be manipulated, altered or spun for political purposes. The decision raises serious questions about the credibility, transparency, and availability of data needed by public health officials, researchers, and physician leaders to advance science-based and data-driven decision-making. The White House has lied enough to show they cannot be trusted with data needed for responses to the COVID19 pandemic such as reopening.

The scientific data is what it is. It has no philosophy, no politics, and is often not what we want it to be. During this pandemic which is the most catastrophic public health disaster since the "Spanish Flu" of 1918, we need scientific leadership to ensure that the data is driving our responses and not being driven by a political agenda. Leaders like Tony Fauci are needed for this pandemic. Others who attempt to undermine Fauci for their own nefarious political purposes will hopefully be ignored by the public. Nonscientific wags who claim scientific abilities they do not have do not really get it. They will likely lead us towards a cataclysmic catastrophe that could be diminished with sensible decisions made on the basis of science rather than politics.

Richard A. Robbins, MD

Editor, SWJPCC

\section{References}

1. Nakamura D. 'Maybe I have a natural ability': Trump plays medical expert on coronavirus by second-guessing the professionals. Washington Post. March 6, 2020. Available at: https://www.washingtonpost.com/politics/maybe-i-have-a- 
natural-ability-trump-plays-medical-expert-on-coronavirus-by-second-quessing-theprofessionals/2020/03/06/3ee0574c-5ffb-11ea-9055-5fa12981bbbf story.html (accessed 7/17/20).

2. Paz C. All the president's lies about the coronavirus. The Atlantic. July 13, 2020. https://www.theatlantic.com/politics/archive/2020/07/trumps-lies-aboutcoronavirus/608647/ (accessed 7/17/20).

3. Coronavirus Resource Center. Johns Hopkins University. Available at: https://coronavirus.jhu.edu/ (accessed 7/17/20).

4. Panetta G. Fauci says he doesn't regret telling Americans not to wear masks at the beginning of the pandemic. Business Insider. Jul 16, 2020. Available at:

https://www.businessinsider.com/fauci-doesnt-regret-advising-against-masks-earlyin-pandemic-2020-7 (accessed 7/17/20).

5. Lahut J. Trump is reportedly getting frustrated with Dr. Fauci's 'blunt approach' during White House press conferences. Business Insider. Mar 23, 2020. Available at: https://www.businessinsider.com/trump-reportedly-growing-frustrated-with-drfaucis-blunt-approach-2020-3 (accessed 7/17/20).

6. Brewster J. Trump retweets call to fire Fauci after he criticized U.S. response to virus. April 13, 2020. Available at:

https://www.forbes.com/sites/jackbrewster/2020/04/13/trump-retweets-call-to-firefauci-after-he-criticized-us-response-to-virus/\#47860ca451d6 (accessed 7/17/20).

7. Pramuk J. White House blocks Fauci from testifying at House coronavirus hearing. CNBC. May 1, 2020. Available at: https://www.cnbc.com/2020/05/01/anthony-fauciblocked-from-testifying-at-house-coronavirus-hearing.html (accessed 7/17/20).

8. Navarro P. Anthony Fauci has been wrong about everything I have interacted with him on. USA Today. July 14, 2020. Available at:

https://www.usatoday.com/story/opinion/todaysdebate/2020/07/14/anthony-fauciwrong-with-me-peter-navarro-editorials-debates/5439374002/ (accessed 7/17/20).

9. Meet the Press. July 12, 2020. https://www.nbcnews.com/meet-thepress/video/adm-brett-grior-dr-fauci-is-not-100-percent-right-about-covid-19response-87536197610 (accessed 7/17/20).

10. Nicholas P, Yong E. 1. Fauci: 'Bizarre' White House Behavior Only Hurts the President. July 15, 2020. Available at:

https://www.theatlantic.com/politics/archive/2020/07/trump-fauci-coronaviruspandemic-oppo/614224/ (accessed 7/17/20).

11. Stelter B. New poll reaffirms that most Americans don't trust the President, but they do trust Dr. Fauci. CNN Business. July 16, 2020. Available at:

https://www.cnn.com/2020/07/15/media/poll-trump-fauci-reliable-sources/index.html (accessed 7/17/20).

12. Samuels B. White House distances itself from Navarro op-ed bashing Fauci. The Hill. 07/15/20. Available at: https://thehill.com/homenews/administration/507406white-house-distances-itself-from-navarro-op-ed-bashing-fauci (accessed 7/17/20).

13. Huang P, Simmons-Duffin S. White House strips CDC of data collection role for COVID-19 hospitalizations. NPR. July 15, 2020. https://www.npr.org/sections/healthshots/2020/07/15/891351706/white-house-strips-cdc-of-data-collection-role-forcovid-19-hospitalizations (accessed 7/17/20). 